\title{
Timeline of Leaf and Cambial Phenology in Relation to Development of Initial Conduits in Xylem and Phloem in Three Coexisting Sub-Mediterranean Deciduous Tree Species
}

\author{
Jožica Gričar ${ }^{1, *} *$, Andreja Vedenik ${ }^{1}$, Gregor Skoberne ${ }^{1}$, Polona Hafner ${ }^{1}$ and Peter Prislan ${ }^{2} \mathbb{D}$ \\ 1 Department of Forest Yield and Silviculture, Slovenian Forestry Institute, 1000 Ljubljana, Slovenia; \\ andreja.vedenik@gozdis.si (A.V.); gregor.skoberne@gozdis.si (G.S.); polona.hafner@gozdis.si (P.H.) \\ 2 Department of Forest Techniques and Economy, Slovenian Forestry Institute, 1000 Ljubljana, Slovenia; \\ peter.prislan@gozdis.si \\ * Correspondence: jozica.gricar@gozdis.si
}

Received: 16 September 2020; Accepted: 15 October 2020; Published: 17 October 2020

\begin{abstract}
It is unclear how the anticipated climate change will affect the timing of phenology of different tree organs/tissues and thus the whole-tree functioning. We examined the timing of leaf phenology and secondary growth in three coexisting deciduous tree species (Quercus pubescens Willd., Fraxinus ornus L. and Ostrya carpinifolia Scop) from a sub-Mediterranean region in 2019. In addition, we investigated the relationship between leaf and cambial phenology and the onset of the potential functioning of initial conduits, as determined by the completed differentiation process (vessels) or final size (sieve tubes). For this purpose, leaf development was monitored and the microcores of cambium and the youngest phloem and xylem increments were repeatedly collected at 7-10-day intervals during the growing season. The results revealed differences in the timing of leaf development and seasonal radial growth patterns in spring among the studied tree species, depending on wood porosity. We found that cambial cell production started in all cases in the first half of March. However, in ring-porous Q. pubescens and F. ornus, radial growth in the stem occurred more than a month before buds were swollen, whereas in diffuse-porous O. carpinifolia, these two events were detected at almost the same time. The end of cambial cell production occurred earliest in F. ornus (mid-July) and two weeks later also in the other two species. The widest initial earlywood vessels and early phloem sieve tubes were found in Q. pubescens, the narrowest initial earlywood vessels in O. carpinifolia and the narrowest early phloem sieve tubes in F. ornus. This indicates differences in the efficiency of conducting systems among the studied species. This novel approach of studying phloem phenology and anatomy in relation to leaf and xylem development contributes to a better understanding of how different tree species adapt their structure of secondary vascular tissues in response to environmental change.
\end{abstract}

Keywords: Quercus pubescens; Fraxinus ornus; Ostrya carpinifolia; earlywood; early phloem; vessel; sieve tube; radial growth

\section{Introduction}

Global warming and the increased frequency and severity of weather events will greatly impact the radial growth patterns of tree species, which adjust their phenology to given environmental cues $[1,2]$. Phenology, the timing of plant seasonal events (e.g., leaf bud burst, flowering, fruiting, cambial activity), ranging from an individual to an ecosystem level, plays a fundamental role in the functioning and productivity of terrestrial ecosystems [3,4]. In deciduous trees, leaf phenology has been proven to be 
a reliable bioindicator of climate change [1]. In contrast, much less is known about the phenology of non-leafy organs and tissues in trees, such as wood, phloem, and fine roots, [5], which could be partly attributed to the greater complexity of monitoring them [6]. Since the phenology of different organs/tissues does not necessarily coincide and is under different biotic and abiotic constraints [5,7], it is unclear how climate change will affect phenological events and thus the whole-tree functioning.

On the landscape scale, vegetation changes can be obtained from remote-sensing data and can be used as an appropriate indicator of broadscale vegetation-climate interactions and associated changes in ecosystem conditions. Vegetation indices can be used, for example, to scale up ground measurements on individual trees to assess the effect of climate extremes on future forest growth [8]. However, since vegetation indices are sensitive to the green biomass of the canopy, the link between the timing of leaf and cambial phenology needs to be provided at individual tree and species levels. Species may have almost synchronous phenologies among individuals or show high levels of intraspecific variation [9]. Thus, to quantify the climatic impacts on future forest growth and vitality realistically, advancing our understanding of the climate sensitivity of leaf and cambial phenologies and their interlinkage is required. A critical first step requires individual tree-level monitoring for different tree species. Several existing studies comparing the timing of leaf development and stem xylem growth in spring [10-14] or autumn $[15,16]$ have revealed that interindividual variability in phenologies depends on numerous factors, such as tree species, tree size, tree age, wood porosity, and environmental conditions.

Leaf and cambial phenology have often been observed in coexisting tree species to evaluate species-specific environmental requirements to accomplish crucial phenological events which determine the vessel size (hydraulic properties) [17]. Wood anatomy, as the final result of radial growth patterns, provides valuable information on how different tree species face climate change. In this sense, much less is known about the response of phloem phenology to environmental change $[18,19]$, which represents a gap in our understanding of the ability of tree species to adapt the structure of their secondary vascular tissues to a shifting phenology [20].

Tree species having different types of wood porosity may coexist, although it is unclear how the porosity will affect their adaptive potential under the influence of changing environmental conditions. One of the most important aspects in this regard is the relationship between leaf phenology and initial earlywood vessel formation in spring [12]. We examined the timing of leaf phenology and secondary growth in three tree species (Quercus pubescens Willd, Fraxinus ornus L. and Ostrya carpinifolia Scop.) in the 2019 growing season. In addition, we investigated the influence of spring phenology on the onset of the potential functioning of initial conduits in the xylem and phloem, as determined by the completed differentiation process (vessels) or size (sieve tubes). We hypothesized that the species-specific timing of leaf and cambial phenology determines the size of initial earlywood vessels and early phloem sieve tubes and their potential conductivity. The study was performed at a sub-Mediterranean site in Slovenia in which the selected tree species prevalent in the forest stands in the past, and their share, have been increasing in recent decades on previously cut-down and denuded karst areas. Such a study has never been performed on F. ornus and O. carpinifolia. The main novelty of our work was to compare phloem formation phenology and initial sieve tube development with leaf phenological observations. New information on the seasonal radial growth patterns of coexisting tree species is a first step towards understanding their adaptation abilities to environmental changes.

\section{Materials and Methods}

\subsection{Study Site Description}

The study was conducted in Podgorski Kras ( $45^{\circ} 32^{\prime} 56.3^{\prime \prime}$ N, $13^{\circ} 54^{\prime} 36.1^{\prime \prime}$ E, 430 m a.s.1.), a karst region in SW Slovenia. The site was abandoned about 30 years ago and since then the grasslands were slowly overgrown by trees and shrubs. The vegetation is uneven, with patches of woody plants interspersed by grassy gaps. Woody plant encroachment is characterized by various mid- and late succession species, with pubescent oak (Quercus pubescens Willd.), manna ash (Fraxinus ornus L.) and 
European hop-hornbeam (Ostrya carpinifolia Scop.) being among the dominant tree species growing in either pure or mixed stands. The most abundant shrubs of early succession stages are Juniperus communis L., Prunus mahaleb L., Cornus mas L., and Cotinus coggygria Scop. The most abundant grassland species that cover around $20 \%$ of the area are Bromopsis erecta, (Huds.) Fourr., Carex humilis Leyss., Stipa eriocaulis Borbás., Centaurea rupestris L., Potentilla tommasiniana F. W. Schultz, Anthyllis vulneraria L., Galium corrudifolium Vill. and Teucrium montanum L. [21]. The average height of the tree layer is $8-10 \mathrm{~m}$; the mean cover of woody species is roughly $55 \%$. The vegetation of the site is mid-successional, indicating that it is composed of species of the former successional stage (calcareous grassland (Carici humilis-Centaureetum rupestris $\mathrm{Ht}$. 1931) and of species of the potential natural vegetation of the area (Ostryo carpinifoliae-Quercetum pubescentis Ht. 1950) [21].

The climate at the study site is sub-Mediterranean, characterized by harsh winter conditions and frequent dry periods in summer. In the period 1992-2019, the average annual air temperature was $11.9^{\circ} \mathrm{C}\left(\mathrm{T}_{\mathrm{Jan}}=2.9^{\circ} \mathrm{C}, \mathrm{T}_{\mathrm{Jul}}=21.5^{\circ} \mathrm{C}\right)$. Precipitation is relatively abundant, about $1300 \mathrm{~mm}$ per year (period 1992-2019), but it is not predictable and not evenly distributed throughout the year. There are usually two annual rainfall peaks, in autumn and in late spring. Shallow limestone soil and frequent wind diminish the impact of high precipitation, resulting in a large proportion of deep percolation loss of soil water and frequent summer droughts [21]. In 2019, the average annual air temperature was $12.9^{\circ} \mathrm{C}\left(\mathrm{T}_{\text {Jan }}=-2.0^{\circ} \mathrm{C}, \mathrm{T}_{\text {Jun }}=22.8^{\circ} \mathrm{C}\right)$ and the total annual precipitation was $1547 \mathrm{~mm}$. The climatic data were obtained from the nearby climate station belonging to the Slovenian Environment Agency (ARSO).

\subsection{Xylem and Phloem Formation}

At the beginning of the 2019 growing season, six dominant or codominant trees per species were selected for leaf phenological observations, as well as for monitoring xylem and phloem formation. The selected trees were without any visible injuries on the tree stem surface. The characteristics of the sampled individuals are presented in Table 1. Leaf phenology was observed on all trees at 7-10-day intervals from March until September and 14-day intervals from September until December 2019. We focused on the period from budburst to full leaf unfolding-i.e., March-May. To document leaf development, images of a selected crown parts were captured on each sampling date with a digital camera. The methodology is described in detail by [19].

Table 1. Characteristics of the sampled trees. Mean values \pm standard deviation.

\begin{tabular}{cccc}
\hline & Fraxinus ornus & Quercus pubescens & Ostrya carpinifolia \\
\hline $\mathrm{DBH}(\mathrm{cm})^{1}$ & $13.5 \pm 5.4$ & $18.9 \pm 4.7$ & $14.3 \pm 2.8$ \\
$\mathrm{H}(\mathrm{m})^{2}$ & $8.9 \pm 1.2$ & $9.8 \pm 1.0$ & $10.0 \pm 1.2$ \\
\hline \multicolumn{3}{c}{}
\end{tabular}

${ }^{1} \mathrm{DBH}$ - Diameter at breast height; ${ }^{2} \mathrm{H}$ - height.

From March until September 2019, microcores $2.4 \mathrm{~mm}$ in diameter using a Trephor tool [22] were collected on the same dates when leaf phenological observations were performed. The microcores were taken in stems at $0.7-1.7 \mathrm{~m}$ above the ground following a helical pattern and separated by $3-5 \mathrm{~cm}$ to avoid wound effects. Each microcore contained phloem, cambium and at least the three youngest xylem rings. Immediately after removal, the microcores were put in $70 \%$ ethanol. In the laboratory, the samples were further processed for preparation of transverse sections stained with safranin and astra blue for light microscopy (see Gričar et al. [19] for details). On the cross-sections, we assessed the following developmental phases of xylem and phloem formation, expressed in days of the year (DOY): (1) onset/end of cambial cell production, (2) appearance of first expanding xylem and phloem cells; (3) final size of initial early phloem sieve tube; (4) appearance of initial earlywood vessels in expansion phase; (5) onset of secondary wall formation and lignification of initial earlywood vessels; (6) first mature initial earlywood vessels; (7) transition from earlywood to latewood; (8) transition from early to late phloem and (9) cessation of wood formation. The determination and definitions of each phase 
are described in Prislan et al. [18] and Gričar et al. [19]. On the cross-sections taken at the end of the growing season of 2019, the final widths of xylem and phloem increments were measured along three radial rows of cells (parallel to the rays) and then averaged (Figure 1). To assess the species-specific differences in conduit size, the tangential diameter and area of the initial earlywood vessels at the growth ring boundary were measured and mean values calculated. In phloem, the tangential diameter and area of 10 randomly selected initial sieve tubes of early phloem were measured and mean values calculated. All observations and measurements of tissues were performed with an image analysis system consisting of an Olympus BX51 (Tokyo, Japan) light microscope, a PIXElink, PL-A66Z digital camera and the NIS-Elements Basic Research V.2.3 image analysis program (Tokyo, Japan).

(a)

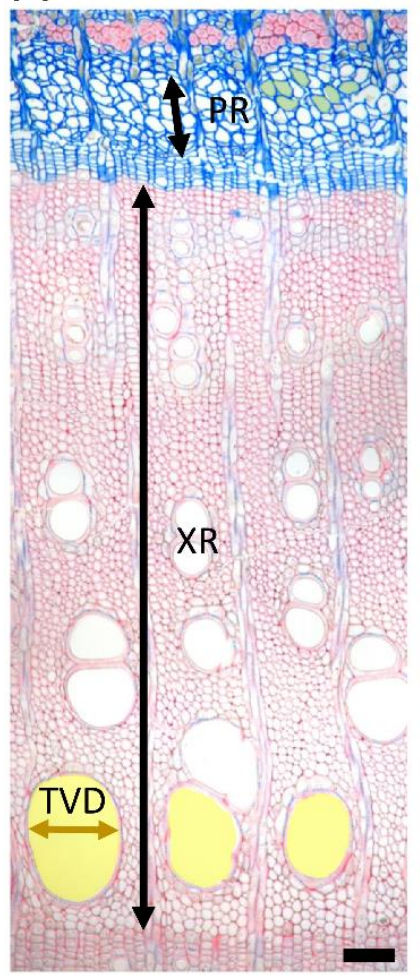

(b)

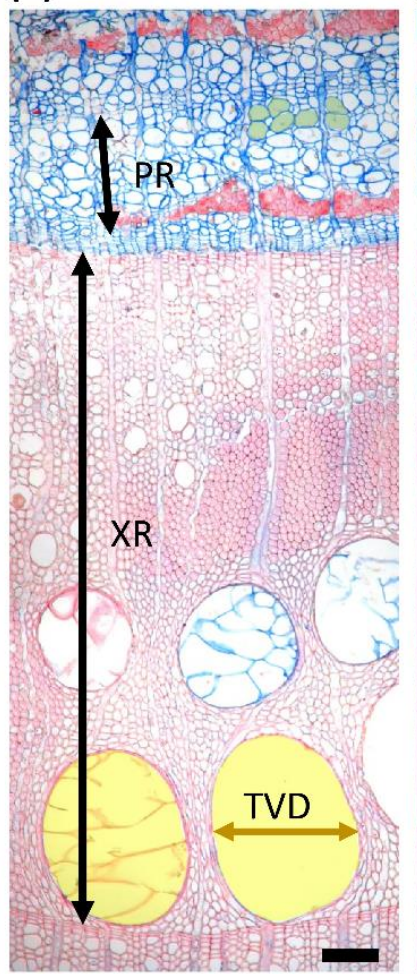

(c)

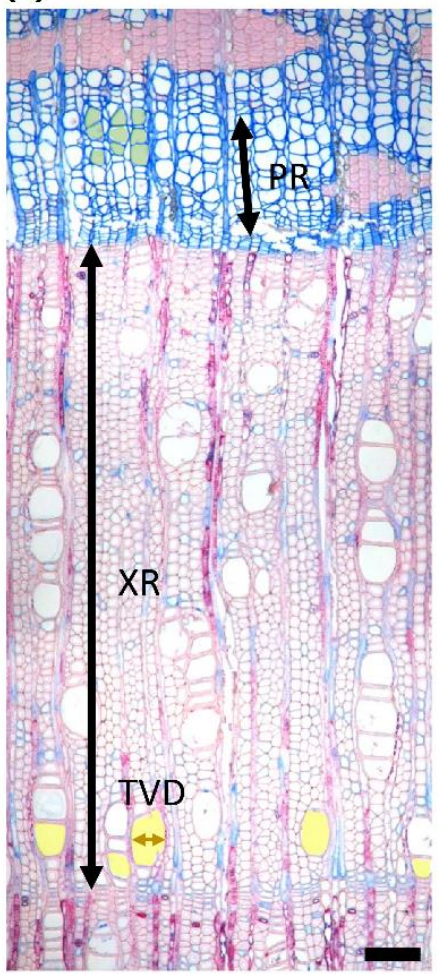

Figure 1. Cross-sections of xylem and phloem increments in 2019 in (a) Fraxinus ornus L., (b) Quercus pubescens Willd. and (c) Ostrya carpinifolia Scop. Area of initial earlywood vessels is marked with yellow; area of early phloem sieve tubes is marked with green color. XR-xylem increment; PR—phloem increment; TVD—tangential diameter of initial earlywood vessels. Scale bars $=100 \mu \mathrm{m}$.

\subsection{Statistical Analysis}

Differences among the three selected species in leaf and xylem/phloem phenology, xylem and phloem ring width and anatomical features (i.e., lumen diameter and area) of initial vessels and sieve cells were determined using a one-way ANOVA followed by Tukey's HSD test. The normality of distribution and homogeneity of variance were verified using the Shapiro-Wilk W test and Levene's test, respectively [23]. If the conditions of normality and homogeneity of variance were not met, the Kruskal-Wallis test was used, followed by the Dunn post-hoc test. In all tests, a 0.05 significance level was used. Data were analyzed using R environment (package agricolae) [24]. 


\section{Results}

\subsection{Timing of Leaf Phenology and Seasonal Radial Growth}

The main milestones of leaf development and radial growth are presented in Figure 2, while the main values ( \pm standard deviation) and the significance of differences $(\alpha \leq 0.05)$ among the tree species are presented in Table 2. The onset of cell division in the cambium was detected in the first half of March in all three deciduous species. Almost simultaneously with cambial reactivation, buds were swollen in diffuse-porous O. carpinifolia, while this happened more than a month later in ring-porous F. ornus and $Q$. pubescens. The time difference between the onset of cambial activity and bud swelling statistically differed $(p=0.001)$ among the species_it was longest in F. ornus $(41.7 \pm 3.4$ days $)$ and shortest in $O$. carpinifolia $(6.0 \pm 0.0$ days). In $Q$. pubescens, it was $34.5 \pm 5.4$ days. Leaf development was fastest in O. carpinifolia; the first leaves emerged more than a month earlier than in the two ring-porous species, and full leaf unfolding occurred by mid-May, followed by $Q$. pubescens and finally F. ornus by the end of May. This leaf phenological stage generally coincided with the transition from early phloem to late phloem in all species and the transition from earlywood to latewood in Q. pubescens and F. ornus. Compared to O. carpinifolia, abundant leaf coloring occurred 2 and 3 weeks earlier in Q. pubescens and F. ornus. A synchrony in leaf phenological phases was observed among individuals of O. carpinifolia. In ring-porous species, a modest degree of interindividual variability in spring leaf phenology (up to 15 days) was observed.

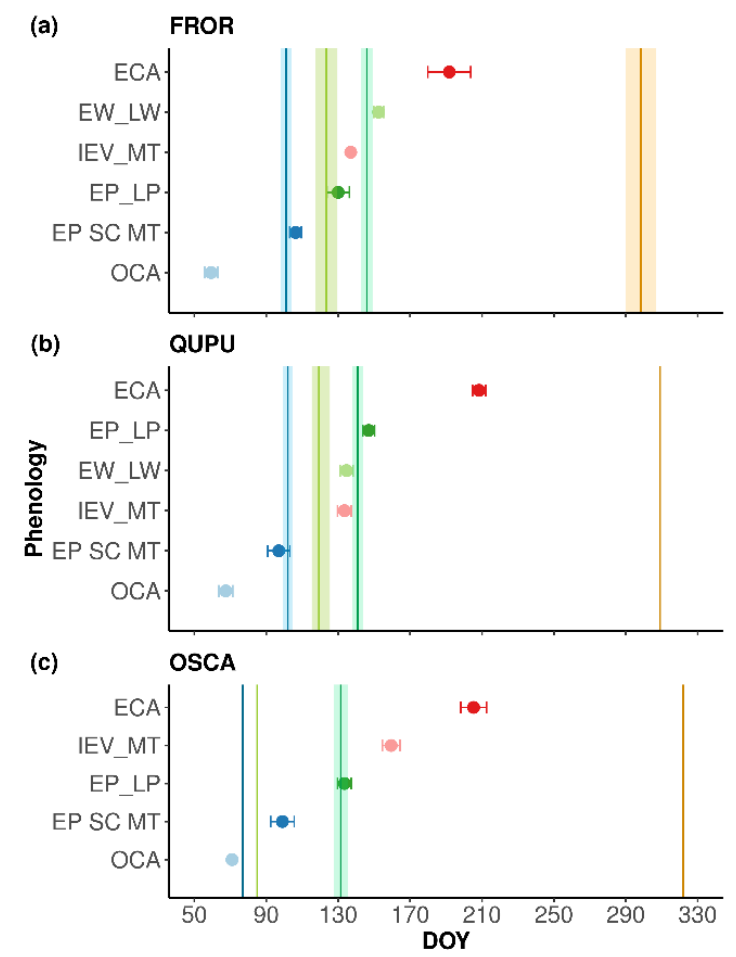

Figure 2. Main leaf phenological phases and timings of xylem and phloem formation for (a) Fraxinus ornus (FROR); (b) Quercus pubescens (QUPU) and (c) Ostrya carpinifolia (OSCA) in Podgorski Kras in 2019. SB-swollen buds (blue line); LE-leaf emergence (light-green line); LU—leaf unfolding (dark-green line); AC—autumn leaf coloring (orange line); OCA—onset of cambial activity (light-blue dot); EP SC MT—-time when initial sieve tubes reached final size (dark-blue dot); EP_LP_transition from early phloem to late phloem (dark-green dot); IEV_MT—mature initial earlywood vessels (light red dot); EW_LW—-transition from earlywood to latewood (light-green dot); ECA—end of cambial activity (dark-red dot). 
Table 2. Phenological phases (DOY = day of the year) of leaf development and of xylem and phloem formation (mean \pm standard deviation). Phenological phases marked with the same letters are not significantly different $(\alpha \leq 0.05)$.

\begin{tabular}{cccc}
\hline & \multicolumn{2}{c}{ Phenological Phases (DOY \pm Standard Deviation) } \\
\cline { 2 - 4 } & Fraxinus ornus & Quercus pubescens & Ostrya carpinifolia \\
\hline Onset of cambial cell production & $59.33 \pm 3.61^{\mathrm{b}}$ & $67.50 \pm 3.83^{\mathrm{a}}$ & $71.00 \pm 0.00^{\mathrm{a}}$ \\
Swollen buds & $101.00 \pm 3.10^{\mathrm{a}}$ & $102.00 \pm 2.45^{\mathrm{a}}$ & $77.00 \pm 0.00^{\mathrm{b}}$ \\
Final size of initial early phloem sieve tube & $106.33 \pm 3.27^{\mathrm{a}}$ & $97.00 \pm 3.27^{\mathrm{b}}$ & $99.00 \pm 6.57^{\mathrm{a}, \mathrm{b}}$ \\
Leaf emergence & $123.50 \pm 6.12^{\mathrm{a}}$ & $119.33 \pm 4.08^{\mathrm{b}}$ & $85.00 \pm 0.00^{\mathrm{c}}$ \\
Transition from early phloem to late phloem & $130.00 \pm 6.26^{\mathrm{b}}$ & $147.00 \pm 3.29^{\mathrm{a}}$ & $133.50 \pm 3.84^{\mathrm{b}}$ \\
Transition from earlywood to latewood & $152.50 \pm 2.74^{\mathrm{b}}$ & $134.67 \pm 3.61^{\mathrm{a}}$ & $/$ \\
Full leaf unfolding & $146.00 \pm 3.10^{\mathrm{a}}$ & $140.83 \pm 2.86^{\mathrm{b}}$ & $131.50 \pm 3.83^{\mathrm{c}}$ \\
Mature initial earlywood vessel & $137.00 \pm 0.00^{\mathrm{b}}$ & $133.50 \pm 3.84^{\mathrm{b}}$ & $159.50 \pm 4.93^{\mathrm{a}}$ \\
End of cambial cell production & $191.83 \pm 11.96^{\mathrm{b}}$ & $208.33 \pm 3.61^{\mathrm{a}}$ & $205.33 \pm 7.17^{\mathrm{a}} \mathrm{b}$ \\
Autumn leaf coloring & $298.33 \pm 8.26^{\mathrm{c}}$ & $309.00 \pm 0.00^{\mathrm{b}}$ & $322.00 \pm 0.00^{\mathrm{a}}$ \\
\hline
\end{tabular}

The cambial cell production period ceased earliest in F. ornus, by mid-July, and by the end of July also in O. carpinifolia and in Q. pubescens (Figure 2, Table 2). Although the period of cell production was the longest in $Q$. pubescens (140.8 \pm 6.9 days) and shortest in F. ornus (132.5 \pm 14.7 days), the widest xylem increments were found in F. ornus and narrowest in Q. pubescens (Figure 3, Table 3). In phloem, the annual increment widths were positively related to the duration of cambial activity. In all cases, xylem increments in 2019 were wider than phloem increments. In F. ornus, the xylem increment was $86 \%$ greater than the phloem increment, $74 \%$ greater in O. carpinifolia and $68 \%$ in Q. pubescens.
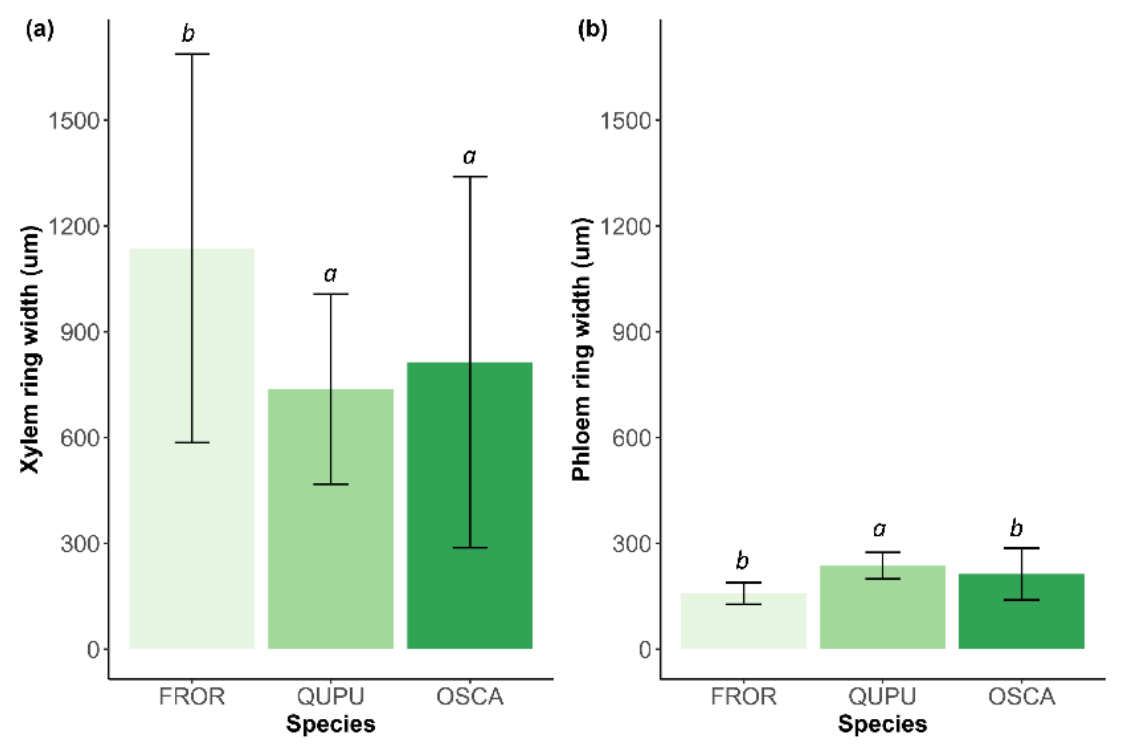

Figure 3. Widths of annual increments in (a) xylem and (b) phloem in Fraxinus ornus (FROR), Quercus pubescens (QUPU) and Ostrya carpinifolia (OSCA) in Podgorski Kras in 2019. For significance letters see Table 3. 
Table 3. Xylem and phloem ring widths and anatomical characteristics of initial earlywood vessels (IEVs) and sieve tubes (mean \pm standard deviation). Characteristics marked with the same letters are not significantly different $(\alpha \leq 0.05)$.

\begin{tabular}{|c|c|c|c|}
\hline & \multicolumn{3}{|c|}{ Xylem and Phloem Characteristics } \\
\hline & Fraxinus ornus & Quercus pubescens & Ostrya carpinifolia \\
\hline Xylem ring width $(\mu \mathrm{m})$ & $1136.7 \pm 550.8^{b}$ & $737.2 \pm 269.9^{a}$ & $814.41 \pm 526.09^{a}$ \\
\hline Phloem ring width $(\mu \mathrm{m})$ & $158.3 \pm 30.4^{\mathrm{b}}$ & $236.8 \pm 37.4^{\mathrm{a}}$ & $213.1 \pm 73.3^{b}$ \\
\hline IEV diameter $(\mu \mathrm{m})$ & $144.1 \pm 20.7^{b}$ & $271.9 \pm 44.8^{\mathrm{a}}$ & $70.3 \pm 10.2^{\mathrm{c}}$ \\
\hline IEV area $\left(\mu \mathrm{m}^{2}\right)$ & $18,011.1 \pm 4629.5^{b}$ & $61,007.9 \pm 15,713.7^{\mathrm{a}}$ & $5216.7 \pm 1406.7^{\mathrm{c}}$ \\
\hline Sieve tube diameter $(\mu \mathrm{m})$ & $34.5 \pm 4.1^{\mathrm{b}}$ & $45.4 \pm 6.4^{\mathrm{a}}$ & $37.5 \pm 4.3^{\mathrm{c}}$ \\
\hline Sieve tube area $\left(\mu \mathrm{m}^{2}\right)$ & $852.7 \pm 166.6^{b}$ & $1213.4 \pm 222.8^{\mathrm{a}}$ & $1038.4 \pm 151.5^{\mathrm{c}}$ \\
\hline
\end{tabular}

\subsection{Development of Initial Conduits in Relation to Leaf Phenology}

In phloem, initial sieve tubes started to expand around the time of cambial reactivation in all species and reached their final size at the time of swollen buds in Q. pubescens and F. ornus. In O. carpinifolia, initial sieve tube expansion was completed 2 weeks after the emergence of the first leaves. The final size of initial sieve tubes, in all cases, indicating their ability to transport assimilates, occurred much earlier than the complete maturation of initial earlywood vessels, indicating their ability to conduct water (Figure 2, Table 2). Sieve tubes thus reached their final size 1 month earlier than initial earlywood vessels which were fully matured in Q. pubescens and F. ornus, and 2 months earlier in O. carpinifolia.

The first initial earlywood vessels appeared earliest in Q. pubescens, at the end of March-i.e., on average 22.5 days after the onset of cambial cell production. In F. ornus and O. carpinifolia, these cells first appeared in mid-April and the end of April, which is 6 and 7 weeks, respectively, after the onset of radial growth. At the time of first leaf emergence, initial earlywood vessels were already in the phase of wall thickening and lignification in Q. pubescens and F. ornus. In O. carpinifolia, only the first expanding xylem cells were detected at that time, whereas expanding initial vessels were observed a month later. Initial vessels thus needed 6 weeks for full development in Q. pubescens, 5 weeks in F. ornus and 5.5 weeks in O. carpinifolia. Compared to leaf phenology they were fully developed 7-9 days before full leaf unfolding in Q. pubescens and F. ornus and 4 weeks after full leaf unfolding in O. carpinifolia.

\subsection{Size of Initial Earlywood Vessels and Early Phloem Sieve Tubes}

The widest initial earlywood vessels and early phloem sieve tubes were found in Q. pubescens, the narrowest initial earlywood vessels in O. carpinifolia and the narrowest early phloem sieve tubes in F. ornus (Figure 4, Table 3). Nevertheless, in all cases, conduits wider in xylem than in phloem were measured; they were $83.3 \%$ wider in Q. pubescens, $76.1 \%$ in F. ornus and $46.7 \%$ in O. carpinifolia. Differences in conduit area were detected, based on differences in conduit size in xylem and phloem. To summarize, initial earlywood vessels in Q. pubescens were $70.5 \%$ and $91.4 \%$ larger than in F. ornus and O. carpinifolia, respectively. Furthermore, early phloem sieve tubes were $29.7 \%$ and $14.4 \%$ larger than in F. ornus and O. carpinifolia, respectively. 

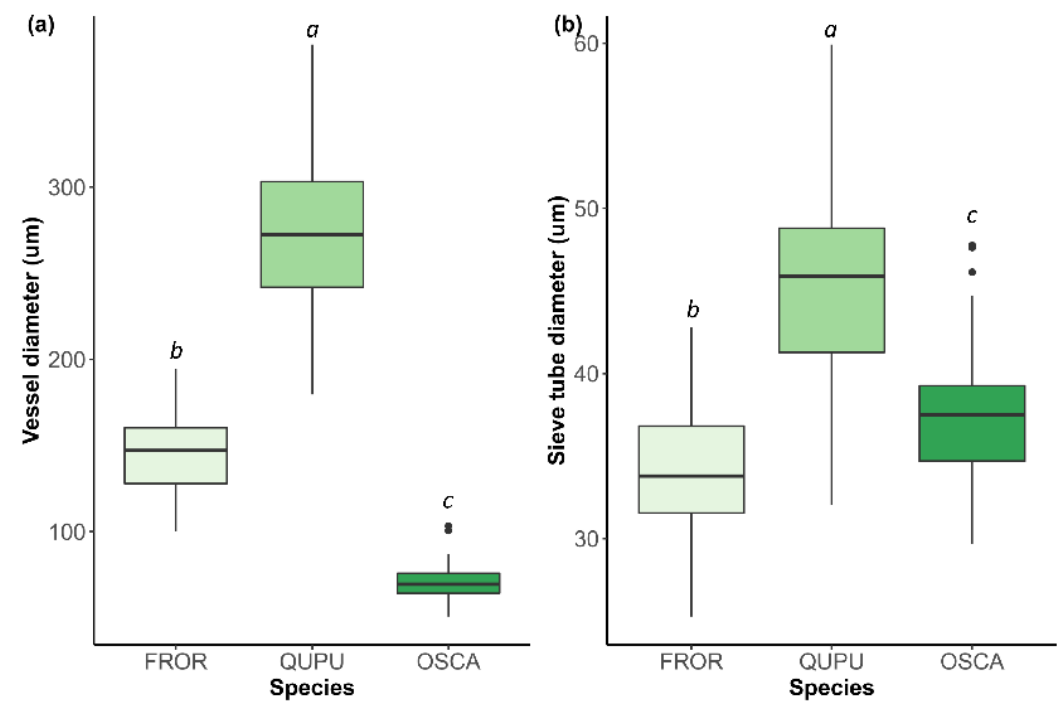

Figure 4. Characteristics of conduits: (a) tangential diameter of initial earlywood vessels; (b) tangential diameter of early phloem sieve tubes in Fraxinus ornus (FROR), Quercus pubescens (QUPU) and Ostrya carpinifolia (OSCA) in Podgorski Kras in 2019.

\section{Discussion}

Our preliminary study of leaf phenology and seasonal radial growth in three coexisting tree species (two ring-porous and one diffuse-porous) revealed different growth patterns among the studied species, which resulted in different xylem and phloem conduit anatomies.

\subsection{Widths of Annual Increments in Relation to Phenology and Weather Conditions}

The results of our study confirmed the hypothesis and are in line with previous reports that the timing of leaf and cambial phenology and their interlinkage is species-specific and largely depends on wood porosity $[10,12]$. We found that, in all cases, cambial cell production started in the first half of March. However, in ring-porous Q. pubescens and F. ornus, radial growth in the stem occurred more than a month before buds were swollen, whereas in diffuse-porous O. carpinifolia, these two events were detected at almost the same time. The end of cambial cell production seemed not to be related to wood porosity; it occurred earliest in F. ornus (mid-July) and almost at the same time in the other two species (second half of July). While the widths of phloem increments were positively related to the duration of the growing season, in xylem, this relation was just the opposite. The phloem increment of 2019 in F. ornus was about 33\% narrower than in Q. pubescens and 10\% narrower than in O. carpinifolia. In contrast, the xylem increment in F. ornus was about $35 \%$ wider than in Q. pubescens and $28 \%$ wider than in O. carpinifolia. The negative relation between the duration of cambial activity and annual xylem widths in F. ornus suggests that the rate of cell production on the xylem side was higher than in the other two species, which was reflected in wider xylem increments. In addition to the duration of the cambial cell production period, the rate of cell division is an important determinant of increment widths $[2,25]$. A detailed analysis of seasonal radial growth was not the subject of the current research; however, only such multi-year data would allow a more detailed comparison of growth rates among the studied species.

For the same reason, a detailed weather-growth analysis could not be performed; we could only compare the phenology and annual increments in a given growing season. Compared to the long-term average (1992-2019), 70\% less precipitation was detected in March 2019-i.e., at the onset of cambial activity and leaf development. May was an abnormally wet month, with $158 \%$ more precipitation, whereas June was an exceptionally dry month, with $89 \%$ less rainfall. It was followed by a dry July, which could explain the cessation of cambial activity in this month. No data exist on the seasonal dynamics of radial growth in F. ornus and O. carpinifolia; it is therefore difficult to 
assess to what extent the dry June/July affected normal cambium rhythm. This is not the case for Q. pubescens, for which, in addition to the data of other researchers [26], we have been monitoring the intra-annual growth of at this site since 2014. The 6-year data record shows that cambial cell production ends in the period mid-July and mid-August, depending on the weather conditions in that year. Low soil water availability in combination with unfavorable growth conditions in June-July (high air temperatures and/or lack of precipitation) may cause the earlier cessation of tree growth in Q. pubescens at Podgorski Kras [27]. However, it also seemed that weather conditions in the driest summer months (second part of July-August) have no major effect on the duration of radial growth, because cambial cell production is usually finished by that time, which might be an adaptation of this species to local environmental conditions in terms of finishing the majority of its radial growth before stressful conditions may appear [26,27]. It can thus be concluded that early onset and early end of cambial activity in combination with intensive growth in favorable months, which was observed in our new studied species, F. ornus, is a good prerequisite for successful growth in Mediterranean environments. Although a single study of radial growth does not allow any reliable comparisons and solid conclusions on the annual growth patterns of the investigated tree species, especially in relation to environmental cues, it does show a species-specific timeline of leaf and cambial phenology and, consequently, of the final widths of xylem and phloem increments.

\subsection{Linkage between Leaf Phenology and Development of Initial Earlywood Vessels}

While the timing of cambial cell production characterizes the timing of the onset of secondary growth, fully differentiated initial conduits indicate the time to the potential functioning of newly formed xylem and phloem cells. Initial earlywood vessels are located at the growth ring boundary and are formed at the onset of the growing season in spring. These initial vessels differ from subsequent earlywood cells because (1) they are formed before (ring-porous species) or during (diffuse-porous species) the early stages of leaf development and (2) they are usually the largest vessels in the xylem increment, which positively influences their water transportation capacity [28]. Different timelines in leaf and cambial phenology depending on wood porosity result in different requirements for non-structural carbohydrates. In ring-porous species, the formation of initial earlywood vessels relies on non-structural carbohydrates produced in previous years and stored in parenchyma cells. In diffuse-porous species, in contrast, initial earlywood vessel development occurs after leaf expansion, so their formation largely depends on recent carbohydrates derived directly from photosynthesis [29,30]. We also found greater interindividual synchrony in the observed leaf phenological phases in diffuse-porous $O$. carpinifolia than in the two ring-porous species.

Our findings are in line with previous reports that initial earlywood vessel formation tends to occur earlier in ring-porous than in diffuse-porous tree species [10,12]. Differences in the timing and rate of initial vessel development were observed between the two ring-porous species. In $Q$. pubescens, the first expanding vessels occurred 11 days earlier and were mature 4 days earlier than in F. ornus. Furthermore, it seems that the development of leaves and initial vessels, when it started, proceeded less intensely in diffuse-porous $O$. carpinifolia than in ring-porous $Q$. pubescens and F. ornus. In relation to leaf phenology, initial earlywood vessels in ring-porous species are formed before full leaf unfolding, to be ready for water transport by the time the canopy is fully developed. Wide earlywood vessels are generally functional only over a short period of time-i.e., in the growing season in which they are formed. It is therefore crucial for newly developed conduits to be operational before maximum transpiration is reached [13,31]. In diffuse-porous O. carpinifolia, the maturation of initial earlywood vessels was completed 4 weeks after full leaf unfolding. Since vessels of multiple years are involved in water transport, the development of new cells is not so critical in terms of tree functioning; it may therefore occur at slower rates [28]. 


\subsection{Characteristics of Initial Earlywood Vessels}

The anatomy and water transport efficiency of conduits are influenced by several species-specific and environmental factors. We found that initial earlywood vessels were considerably larger in Q. pubescens than in the other two species, which leads to a differently efficient conducting system in xylem. Because the hydraulic efficiency of a vessel increases proportionally to the fourth power of its radius (Hagen-Poiseuille law) there is a strong vessel size-conductivity relationship, meaning that even small differences in vessel size drastically change water transport efficiency and security [31]. Based on the data, we can assume that the most efficient water transport is provided in Q. pubescens and the least in O. carpinifolia. At the same time, the risk of breakage of the water column due to embolism under drought stress is higher in wider conduits (in Q. pubescens in our case) than in smaller ones and can jeopardize tree viability. In ring-porous species, the dysfunction of wide earlywood vessels from embolism and tyloses occurs within a year of their formation [13,32], although much less efficient, small-diameter latewood vessels may remain functional for many years. The combination of wide earlywood and narrow latewood vessels in ring-porous species thus guarantees efficient and safe water transport [13], even in the case of stressful events, and may function to prevent complete transport failure [28]. In temperate diffuse-porous species, the diameter of earlywood vessels is smaller than in ring-porous species. In addition, differences in the size of earlywood and latewood vessels are much less pronounced, which results in similar water transportation capacity.

\subsection{Linkage between Leaf Phenology and Development and Size of Initial Early Phloem Sieve Tubes}

Unlike with xylem phenology, the relationship between leaf phenology and phloem development is generally poorly characterized in most tree species, which contrasts with its crucial role in a tree to provide the long-distance transport of photosynthates and signaling molecules among different organs/tissues [20]. Consequently, little is known about the links among phloem anatomy, transport capacity and vulnerability to environmental cues [33,34].

We found that the differentiation of the initial early phloem sieve tubes started at the same time as cell production, which is in agreement with previous observations in temperate deciduous species [18]. These cells reached their final size either at the time of swollen buds in Q. pubescens and F. ornus (ring-porous) or 2 weeks after first leaf emergence in O. carpinifolia (diffuse-porous). As with initial earlywood vessel development, the growth of early phloem sieve tubes in ring-porous species also seemed to be fueled by storage reserves, whereas newly formed photosynthates are required in diffuse-porous species. Different strategies to overwinter and reactivate sieve tubes in spring have previously been found. In Fagus sylvatica-for example, phloem formation started with the expansion of the overwintered early phloem sieve tubes next to the cambium at the onset of cambial reactivation [18]. However, to ensure sufficient photosynthate transport to the developing tissues, the late phloem formed in the previous growing season continued functioning until a sufficient amount of newly formed sieve tubes had been formed to be able to take on this task [18]. The methods for sample preparation and light microscopy used in the paper did not allow more detailed observations of the seasonal changes and functionality of xylem and phloem cells. For a better understanding of sieve tube functionality and age-related changes, such as their collapse and death, which ultimately ceases their conducting function, proper sample preparation and examination at higher resolutions with more sophisticated equipment (e.g., SEM, TEM) is required [18].

Differences in the widths of phloem increments and the size of early phloem conduits were found. These two phloem parameters were positively related, with the highest values found in Q. pubescens and the lowest in F. ornus. Q. pubescens, with $33 \%$ and $10 \%$ wider increments than F. ornus and $O$. caprinifolia, respectively. Furthermore, $Q$. pubescens had $24 \%$ and $17 \%$ wider increments than $F$. ornus and O. caprinifolia, respectively. The results indicate differences in the efficiency of phloem conducting systems among the studied species. To compare and evaluate seasonal differences in the efficiency of conducting phloem, analyses of cell characteristics and cell types in the non-collapsed phloem part are needed. In temperate tree species, the structure of early and late phloem differs and defines the 
prevailing function. Large early phloem sieve tubes are involved in conducting, whereas a high share of axial parenchyma in late phloem indicates the importance of the storage function [35]. So, not only the morphology of conducting cells but also the quantity of storage tissue (parenchyma), mainly located in late phloem, influence whole-tree transport processes and resource partitioning [36].

\subsection{Hormonal Control of Xylem and Phloem Development}

The onset of radial growth before bud break in ring-porous species is explained by hormonal regulation in terms of increased cambium sensitivity to auxin [37]. This enhanced cambium sensitivity to extremely low auxin concentrations enables the development of large initial earlywood vessels within a limited period of time in early spring. Increased cell expansion before secondary wall deposition permits the formation of very wide earlywood vessels. In diffuse-porous tree species, conversely, a low cambium sensitivity to auxin and the formation of initial earlywood vessels after first leaf emergence (i.e., 5 weeks in O. carpinifolia), which requires high auxin concentrations, results in narrow vessels [38]. Similarly, the development of initial sieve tubes in early phloem occurs before bud break and the remaining early phloem portion is formed in the period of early leaf development, when only low-concentration auxin streams are produced. Changes in auxin concentrations may explain the development of the two vascular tissues in trees: low concentrations induce sieve tube formation in phloem, whereas high concentrations induce vessel formation in xylem. Thus, auxin concentration-driven process can be modulated by changes in cambial sensitivity to auxin are the cause of phloem growth preceding that of xylem at the beginning of the growing season [39].

The transition from early to late phloem and, in ring-porous species also, the transition from earlywood to latewood, occurred in the period of full leaf unfolding. These transitions result in structural changes in xylem and phloem and are induced by hormonal signals originating from developing and fully developed leaves [37]. Unlike young leaves, which produce auxin, which stimulates sieve tube and vessel formation [40], mature leaves induce gibberellins [41], which stimulate the development of fibers in xylem and phloem [37]. In Q. pubescens and O. carpinifolia, fibers are present in late phloem. In Q. pubescens, the onset of wall thickening helps to denote the transition from early to late phloem, whereas in O. carpinifolia, this differentiation stage was detected around 2 weeks later. In F. ornus, no fibers occur in late phloem of the current increment. However, a sclerification of parenchyma cells occurred in the previous phloem increment (formed in 2018) at the end of June-i.e., a month after full leaf unfolding.

\section{Conclusions}

The effect of spring phenology on the conduit size in xylem and phloem in three coexisting sub-Mediterranean tree species (two ring-porous and one diffuse-porous) was first addressed in our study. Such data are generally lacking for F. ornus and O. capinifolia, two of the most common deciduous tree species in sub-Mediterranean forests. Although their wood is of low economic interest (e.g., fodder for livestock, firewood), their ecological relevance for the reforestation of degraded or poor soils has been recognized. In addition, Mediterranean forest types are projected to increase in Central Europe due to climate change $[7,42]$, which has led to a growing interest in the wood properties of these tree species [43,44]. Information on the seasonal dynamics of radial growth are thus essential in terms of carbon allocation and tree hydraulics. Data on longer temporal and spatial scales are undoubtedly needed; however, our preliminary results during one growing season provide valuable information on the chronological sequence of leaf phenology and seasonal radial growth in different tree species. Since the timing of leaf and cambial phenology and their interlinkage is species-specific, phenological observations in trees should encompass data on seasonal radial growth, crucial processes for tree functioning, to improve the accuracy of dynamic global vegetation models that aim to understand and predict the responses of terrestrial ecosystems to environmental changes [6,7]. 
Author Contributions: Conceptualization, J.G. and P.P.; methodology, J.G.; validation, P.P.; formal analysis, A.V., G.S., P.H., P.P. and J.G.; investigation, A.V., G.S., P.H.; resources, A.V., P.P. and J.G.; data curation, A.V., G.S., P.H. and J.G.; writing-original draft preparation, J.G.; writing—review and editing, P.P., P.H.; visualization, P.P.; supervision, J.G.; project administration, J.G.; funding acquisition, J.G. All authors have read and agreed to the published version of the manuscript.

Funding: This research was funded by the Slovenian Research Agency, through research core funding no. P4-0107 (Forest Biology, Ecology and Technology) and projects J4-7203 and J4-9297.

Acknowledgments: The authors gratefully acknowledge the help of Robert Krajnc in the field and laboratory. We thank Zlatko Rojc for his permission to perform the study on the plot, and Martin Cregeen for language editing. We thank the reviewers for their valuable comments and suggestions, which improved the quality of the paper.

Conflicts of Interest: The authors declare no conflict of interest.

\section{References}

1. Menzel, A.; Sparks, T.H.; Estrella, N.; Koch, E.; Aasa, A.; Ahas, R.; Alm-KÜBler, K.; Bissolli, P.; BraslavskÁ, O.G.; Briede, A.; et al. European phenological response to climate change matches the warming pattern. Glob. Chang. Biol. 2006, 12, 1969-1976. [CrossRef]

2. Rossi, S.; Anfodillo, T.; Čufar, K.; Cuny, H.E.; Deslauriers, A.; Fonti, P.; Frank, D.; Gričar, J.; Gruber, A.; King, G.M.; et al. A meta-analysis of cambium phenology and growth: Linear and non-linear patterns in conifers of the northern hemisphere. Ann. Bot. 2013, 112, 1911-1920. [CrossRef] [PubMed]

3. Chuine, I. Why does phenology drive species distribution? Philos. Trans. R. Soc. B Biol. Sci. 2010, 365, 3149-3160. [CrossRef] [PubMed]

4. Stucky, B.J.; Guralnick, R.; Deck, J.; Denny, E.G.; Bolmgren, K.; Walls, R. The Plant Phenology Ontology: A New Informatics Resource for Large-Scale Integration of Plant Phenology Data. Front. Plant Sci. 2018, 9. [CrossRef]

5. Delpierre, N.; Vitasse, Y.; Chuine, I.; Guillemot, J.; Bazot, S.; Rutishauser, T.; Rathgeber, C.B.K. Temperate and boreal forest tree phenology: From organ-scale processes to terrestrial ecosystem models. Ann. For. Sci. 2016, 73, 5-25. [CrossRef]

6. He, M.; Yang, B.; Shishov, V.; Rossi, S.; Bräuning, A.; Ljungqvist, F.C.; Grießinger, J. Relationships between Wood Formation and Cambium Phenology on the Tibetan Plateau during 1960-2014. Forests 2018, 9, 86. [CrossRef]

7. Buras, A.; Menzel, A. Projecting Tree Species Composition Changes of European Forests for 2061-2090 Under RCP 4.5 and RCP 8.5 Scenarios. Front. Plant Sci. 2019, 9. [CrossRef] [PubMed]

8. Decuyper, M.; Chávez, R.O.; Čufar, K.; Estay, S.A.; Clevers, J.G.P.W.; Prislan, P.; Gričar, J.; Črepinšek, Z.; Merela, M.; de Luis, M.; et al. Spatio-temporal assessment of beech growth in relation to climate extremes in Slovenia-An integrated approach using remote sensing and tree-ring data. Agric. For. Meteorol. 2020, 287, 107925. [CrossRef]

9. Park, J.Y.; Muller-Landau, H.C.; Lichstein, J.W.; Rifai, S.W.; Dandois, J.P.; Bohlman, S.A. Quantifying Leaf Phenology of Individual Trees and Species in a Tropical Forest Using Unmanned Aerial Vehicle (UAV) Images. Remote Sens. 2019, 11, 1534. [CrossRef]

10. Suzuki, M.; Yoda, K.; Suzuki, H. Phenological comparison on the onset of vessel formation between ring-porous and diffuse-porous deciduous trees in a Japanese temperate forest. Iawa J. 1996, 17, 431-444. [CrossRef]

11. Sass-Klaassen, U.; Sabajo, C.R.; den Ouden, J. Vessel formation in relation to leaf phenology in pedunculate oak and European ash. Dendrochronologia 2011, 29, 171-175. [CrossRef]

12. Takahashi, S.; Okada, N.; Nobuchi, T. Relationship between the timing of vessel formation and leaf phenology in ten ring-porous and diffuse-porous deciduous tree species. Ecol. Res. 2013, 28, 615-624. [CrossRef]

13. Kitin, P.; Funada, R. Earlywood vessels in ring-porous trees become functional for water transport after bud burst and before the maturation of the current-year leaves. Int. Assoc. Wood Anat. 2016, 37, 315. [CrossRef]

14. Puchałka, R.; Koprowski, M.; Gričar, J.; Przybylak, R. Does tree-ring formation follow leaf phenology in Pedunculate oak (Quercus robur L.)? Eur. J. For. Res. 2017, 136, 259-268. [CrossRef]

15. Dox, I.; Gričar, J.; Marchand, L.J.; Leys, S.; Zuccarini, P.; Geron, C.; Prislan, P.; Mariën, B.; Fonti, P.; Lange, H.; et al. Timeline of autumn phenology in temperate deciduous trees. Tree Physiol. 2020, 40, 1001-1013. [CrossRef] [PubMed] 
16. Marchand, L.J.; Dox, I.; Gričar, J.; Prislan, P.; Leys, S.; Van den Bulcke, J.; Fonti, P.; Lange, H.; Matthysen, E.; Peñuelas, J.; et al. Inter-individual variability in spring phenology of temperate deciduous trees depends on species, tree size and previous year autumn phenology. Agric. For. Meteorol. 2020, 290, 108031. [CrossRef]

17. Pérez-de-Lis, G.; Rossi, S.; Vázquez-Ruiz, R.A.; Rozas, V.; García-González, I. Do changes in spring phenology affect earlywood vessels? Perspective from the xylogenesis monitoring of two sympatric ring-porous oaks. New Phytol. 2016, 209, 521-530. [CrossRef] [PubMed]

18. Prislan, P.; Gričar, J.; de Luis, M.; Smith, K.T.; Čufar, K. Phenological variation in xylem and phloem formation in Fagus sylvatica from two contrasting sites. Agric. For. Meteorol. 2013, 180, 142-151. [CrossRef]

19. Gričar, J.; Lavrič, M.; Ferlan, M.; Vodnik, D.; Eler, K. Intra-annual leaf phenology, radial growth and structure of xylem and phloem in different tree parts of Quercus pubescens. Eur. J. For. Res. 2017, 136, 625-637. [CrossRef]

20. Savage, J.A. It's all about timing-or is it? Exploring the potential connection between phloem physiology and whole plant phenology. Am. J. Bot. 2020, 107, 848-851. [CrossRef]

21. Ferlan, M.; Eler, K.; Simončič, P.; Batič, F.; Vodnik, D. Carbon and water flux patterns of a drought-prone mid-succession ecosystem developed on abandoned karst grassland. Agric. Ecosyst. Environ. 2016, 220, 152-163. [CrossRef]

22. Rossi, S.; Anfodillo, T.; Menardi, R. Trephor: A new tool for sampling microcores from tree stems. Iawa J. 2006, 27, 89-97. [CrossRef]

23. Quinn, G.K.M. Experimental Design and Data Analysis for Biologists, 1st ed.; Cambridge University Press: Cambridge, UK, 2002.

24. R Core Team. R: A language and Environment for Statistical Computing; R Foundation for Statistical Computing: Vienna, Austria, 2018.

25. Skene, D.S. The kinetics of tracheid development in Tsuga canadensis Carr and its relation to tree vigour. Ann. Bot. 1972, 36, 179-187. [CrossRef]

26. Zweifel, R.; Zimmermann, L.; Zeugin, F.; Newbery, D.M. Intra-annual radial growth and water relations of trees: Implications towards a growth mechanism. J. Exp. Bot. 2006, 57, 1445-1459. [CrossRef]

27. Gričar, J.; Zavadlav, S.; Jyske, T.; Lavrič, M.; Laakso, T.; Hafner, P.; Eler, K.; Vodnik, D. Effect of soil water availability on intra-annual xylem and phloem formation and non-structural carbohydrate pools in stem of Quercus pubescens. Tree Physiol. 2018, 39, 222-233. [CrossRef]

28. Taneda, H.; Sperry, J.S. A case-study of water transport in co-occurring ring- versus diffuse-porous trees: Contrasts in water-status, conducting capacity, cavitation and vessel refilling. Tree Physiol. 2008, 28, 1641-1651. [CrossRef]

29. Barbaroux, C.; Bréda, N.; Dufrêne, E. Distribution of above-ground and below-ground carbohydrate reserves in adult trees of two contrasting broad-leaved species (Quercus petraea and Fagus sylvatica). New Phytol. 2003, 157, 605-615. [CrossRef]

30. Michelot, A.; Simard, S.; Rathgeber, C.; Dufrêne, E.; Damesin, C. Comparing the intra-annual wood formation of three European species (Fagus sylvatica, Quercus petraea and Pinus sylvestris) as related to leaf phenology and non-structural carbohydrate dynamics. Tree Physiol. 2012, 32, 1033-1045. [CrossRef]

31. Tyree, M.T.; Zimmermann, M.H. Xylem Structure and the Ascent of Sap, 2nd ed.; Springer: Berlin/Heidelberg, Germany; New York, NY, USA, 2010.

32. Cochard, H.; Tyree, M.T. Xylem dysfunction in Quercus: Vessel sizes, tyloses, cavitation and seasonal changes in embolism. Tree Physiol 1990, 6, 393-407. [CrossRef]

33. Kiorapostolou, N.; Petit, G. Similarities and differences in the balances between leaf, xylem and phloem structures in Fraxinus ornus along an environmental gradient. Tree Physiol. 2018, 39, 234-242. [CrossRef]

34. Sevanto, S.; Ryan, M.; Dickman, L.T.; Derome, D.; Patera, A.; Defraeye, T.; Pangle, R.E.; Hudson, P.J.; Pockman, W.T. Is desiccation tolerance and avoidance reflected in xylem and phloem anatomy of two coexisting arid-zone coniferous trees? Plantcell Environ. 2018, 41, 1551-1564. [CrossRef] [PubMed]

35. Barbaroux, C.; Bréda, N. Contrasting distribution and seasonal dynamics of carbohydrate reserves in stem wood of adult ring-porous sessile oak and diffuse-porous beech trees. Tree Physiol. 2002, 22, 1201-1210. [CrossRef]

36. Spicer, R. Symplasmic networks in secondary vascular tissues: Parenchyma distribution and activity supporting long-distance transport. J. Exp. Bot. 2014, 65, 1829-1848. [CrossRef] [PubMed] 
37. Aloni, R. Ecophysiological implications of vascular differentiation and plant evolution. Trees 2015, 29, 1-16. [CrossRef]

38. Aloni, R. Differentiation of Vascular Tissues. Annu. Rev. Plant Physiol. 1987, 38, 179-204. [CrossRef]

39. Aloni, R. Foliar and axial aspects of vascular differentiation: Hypotheses and evidence. J. Plant Growth Regul. 2001, 20, 12. [CrossRef]

40. Aloni, R.; Alexander, J.D.; Tyree, M.T. Natural and experimentally altered hydraulic architecture of branch junctions in Acer saccharum Marsh. and Quercus velutina Lam. trees. Trees 1997, 11, 255-264. [CrossRef]

41. Dayan, J.; Voronin, N.; Gong, F.; Sun, T.-p.; Hedden, P.; Fromm, H.; Aloni, R. Leaf-Induced Gibberellin Signaling Is Essential for Internode Elongation, Cambial Activity, and Fiber Differentiation in Tobacco Stems. Plant Cell 2012, 24, 66-79. [CrossRef]

42. Hanewinkel, M.; Cullmann, D.A.; Schelhaas, M.-J.; Nabuurs, G.-J.; Zimmermann, N.E. Climate change may cause severe loss in the economic value of European forest land. Nat. Clim. Chang. 2013, 3, $203-207$. [CrossRef]

43. Todaro, L.; Rita, A.; Negro, F.; Moretti, N.; Saracino, A.; Zanuttini, R. Behavior of pubescent oak (Quercus pubescens Willd.) wood to different thermal treatments. Iforest Biogeosci. For. 2015, 8, 748-755. [CrossRef]

44. Humar, M.; Balzano, A.; Grbec, S.; Gričar, J.; Kržišnik, D.; Lesar, B.; Vek, V. Investigation of the material resistance and moisture performance of pubescent oak (Quercus pubescens). Holzforschung 2020. [CrossRef]

Publisher's Note: MDPI stays neutral with regard to jurisdictional claims in published maps and institutional affiliations. 